\title{
Measuring dimensions of service quality
}

\author{
Dejan Tešić \\ University of East Sarajevo Faculty of Economics Brčko, Brčko, Bosnia and Herzegovina
}

\begin{abstract}
In the modern business environment, service companies face the challenge of continuous improvement of the quality of services. Retail managers must use an adequate system for evaluating the quality of the services they provide within the retail establishment. One of the tools that managers use is SERVQUAL analysis, which consists of five dimensions in the traditional model. The aim of this paper is to highlight the importance and necessity of measuring the dimensions of service quality in retail outlets. The subject of this paper is investigating the attitudes of customers in a retail store in Bosnia and Herzegovina, on the perception and expectations of the quality of services provided to them. The results of the study indicate that the gap between performance and expectations of all dimensions is negative, i.e. that none of the performance according to the dimensions of the SERVQUAL model exceeded respondents' expectations.
\end{abstract}

Keywords

services, quality, SERVQUAL, satisfaction, retail.

\section{Introduction}

Companies facing a modern business environment face many challenges. Constant changes in the macro and microenvironment affect businesses, in all branches of the economy, without exception. Business turbulence is felt by both large and small businesses. Large businesses, of course, find it easier to withstand environmental hazards (risks) than SMEs. Small and medium-sized enterprises are especially vulnerable to the dangers that lurk in their environment, and in the first place are the danger of competition, but also of the loss of clients, i.e. customers.

Regardless of the industry, SMEs need to understand the importance of customers in the value chain they create. Of course, other elements of the microenvironment need to be monitored, but it is customers who are essential to the business success. It is for this reason that businesses seek to attract and retain the required number of profitable customers, which is not an easy task at all. According to Prdić, Kuzman and Damjanović (2019) "in the case of service companies, safeness and quality of provided services, with all following elements, give basic conditions for selling products of high quality."

Manufacturing companies differentiate their offer more easily than service companies and adapt more readily to customer needs, primarily because of the tangibility characteristic. In relation to products, services have certain specificities. According to Veljković (2009), the most significant specificities of services are: intangibility, heterogeneity (variability), simultaneity (inseparability) of production and consumption of the service, and perishability (sustainability) of the service.

These specificities of services also give a different view of the quality of services compared to the quality of tangible products. In order for service companies to be successful, it is necessary to first and foremost adequately manage the front line employees. In the contemporary environment, if we look at the specificity of variability, i.e. absence of standardization, because of overcoming this problem, integration of employees and digitization is very important. The authors Mitea (2018), Vochozka, Kliestik, Kliestikova and Sion (2018), Nica (2018), Hyers and Kovacova (2018) and Bolton, Machová, Kovacova and Valaskova (2018) are concerned in their papers with the automation of work and the collaboration of workers with the solutions offered by modern technology.

Authors Grubor, Đokić and Milićević (2017), Končar and Leković (2016), Nuševa and Marić (2017), and Končar, Grubor and Marić (2019) also 
write about the importance of digitalisation in retail.

When it comes to tangible products, most attention is paid to the technical aspect of quality. In the case of services, however, it is slightly different and service companies focus on customer-based quality. According to this concept, quality is what the user says gives him satisfaction.

In relation to the technical, i.e. production observation of quality, the concept of quality as satisfaction is difficult to measure. The author Suuroja (2003) states that service quality and satisfaction are two different concepts and that service quality cannot be equated with customer satisfaction when using the service, but as a result of comparing expectations with the performance provided by the service. In this regard, authors Seth, Deshkmuk, and Vrat (2005) analyse 19 models of service quality, indicating differences in observations of dimensions of service quality by different authors.

However, in addition to the many quality dimension models, there are two widely accepted service quality models, the GAP model and the SERVQUAL model. The GAP model starts from the difference in the perception of the user of the service with the expectations that he had before using the service. The SERVQUAL model uses the GAP model as a basis, and according to Veljković (2009), it represents a "multidimensional scale to compare consumer perceptions with expectations regarding service quality". The following section will provide an overview of recent literature by authors dealing with the SERVQUAL model and its practical application, and then the results of customer satisfaction surveys using the SERVQUAL model in a retail facility operating in the Brcko District of Bosnia and Herzegovina will be presented.

The need for research into the dimensions of the SERVQUAL model is the small number of published papers in this field in Bosnia and Herzegovina. In addition, the topic is significant for practical application in retail stores and can serve retail store managers in planning, implementing, and controlling strategies to improve the quality of services provided. The aim of the paper is to point out the importance of understanding the concept of service quality, its dimensions and how to measure dimensions. The subject of this paper is the analysis of the quality of service, using the SERVQUAL model, on the example of users of services of a service company that performs its business in the territory of Brcko
District. The paper is structured in such a way that it consists of an introduction, literature review, research methodology, research results, discussion and conclusion.

\section{Literature review}

According to Veljkovic (2009), the SERVQAL model is used to compare consumer perceptions with their expectations. According to this model, there are five dimensions of service quality: reliability, responsibility, security, empathy and tangible elements. Consumer perceptions are measured on a Likert scale from 1 (one) to 7 (seven), where 1 (one) represents the lowest and 7 (seven) the highest degree of agreement with the statement that is offered. The SERVQUAL model involves the creation of a questionnaire that, on one hand, measures the performance of a particular company in the eyes of the service user, and on the other, measures the "ideal" customer expectations of the service they used. This results in discrepancies between performance and expectations, which can then be compared to a "world-class company" or another benchmark in the same business. The SERVQUAL model is a widely accepted model used in the business and final consumer markets, in the for-profit and nonprofit sectors, as well as in various service industries. In favour of all of the above are the papers of the authors that we will presented below, which are written on the topic of SERVQUAL model application in retail.

Authors Naik, Gantasala, and Prabhakar (2010) investigate the impact of service quality on retail customer satisfaction. The aim of the paper is to describe the importance of quality of service in retail and to consider which dimensions of service quality are crucial for customer satisfaction. The survey was conducted at retail outlets in India and the conclusion of the survey is that customers have the highest expectations of speed of service execution and payment security, and the lowest expectations of hygiene and ambience as a dimension of quality. When looking at performance, the respondents rated the flow rate at the exit cassettes best, and the lowest performance rating was given to the dimension related to the willingness of staff to respond to customer demands.

Lee-Ross (2008) conducts exploratory research on the contextual stability of SERVQUAL models in three retail clusters in Australia. The results of the research indicate that the five-factor structure of service quality dimensions does not correspond 
to the measurement of quality dimensions in retail outlets that were the subject of the survey. The author concludes that evaluation of the quality of services with smaller dimensions would be more appropriate for the mentioned retail stores, and suggests that in the future the existing dimensions of quality should be revised and new instruments for measuring the quality of services should be developed.

To, Tham and Cheung (2013) explore how customers evaluate the quality of service in retail in China. Research has shown that the classic SERVQUAL model does not fit universally for research in all service branches. SERVQUAL questionnaires should be tailored to different service branches and even, in individual cases, to individual service companies.

Sum and Hui (2009) investigate which dimension of sales staff quality has the greatest impact on customer loyalty in Hong Kong. In addition to the aforementioned connection, the authors also examine the relationship of sales staff quality dimensions with customer loyalty, looking at price levels and customer demographic characteristics. The research conclusion is that sales staff empathy is the dimension that most influences customer loyalty, but only when viewed separately from price and customer demographic characteristics. When talking about the sales staff reliability dimension, that dimension is related to customer loyalty and customer demographic characteristics, but not price.

Martinelli and Balboni (2012) state that service quality is crucial in creating retail customer loyalty. In their research in supermarkets in Italy, the authors conclude that, by looking at the dimensions of service quality, physical attributes and responsibility have the greatest impact on customer loyalty. The research findings also confirm the crucial role of perceived service quality with the indirect role of customer satisfaction in generating customer loyalty.

Khare (2013) explores the impact of the hedonistic and utilitarian customer view on service quality perceptions. The subject of research is small retail stores. The results of the survey indicate that customers consider the importance of staff behavior, lending to purchases, and social relationships when evaluating the quality of service provided. Ambient does not play a crucial role in evaluating the quality of service. Assessing quality dimensions and ranking their importance also depends on whether the buyer has hedonistic or utilitarian buying motives.
Evanschitzky, Iyer, and Caemmerer (2008) explore the relationship of customer satisfaction with the dimensions of service quality. In addition to the dimensions offered by SERVQUAL analysis, the authors also examine the impact of alternative dimensions of service quality on customer satisfaction. The research was conducted in Germany and the conclusion of the research is that alternative quality dimensions, which are not conceptualized as in the SERVQAL model, give better results when it comes to linking quality dimensions with satisfaction.

In their research, Clottey, Collier, and Stodnick (2008) focus on the impact of product quality, service quality, and brand image on customer loyalty in the United States. The research results confirm all three research hypotheses that product quality, quality of service and brand image affect customer loyalty, and the authors also provide regression analysis results that can have practical implications for managers if they want to influence customer loyalty.

Nadiri and Tümer (2009) analyse the quality of service and customer behavior in Cyprus. The results of multiple regression analysis suggest that all dimensions of SERVQUAL model quality affect customer behavior. In addition, the authors conclude that repurchase intentions, as well as purchase recommendations given to other potential buyers, are also related to the dimensions of service quality. When looking at the demographic characteristics of the respondents, it is interesting to conclude that higher-than-average customers have lower expectations of the physical attributes of a retail store compared to lower-income customers, and that married customers have higher expectations of ambience than those who they are not married.

Kimani, Kagira, Kendi and Wawire (2012) explore customer perceptions of service dimensions in retail stores in Kenya. The authors seek to determine the difference in the perception of quality between supermarkets and smaller standalone shops. The results of the research show that when it comes to smaller standalone shopping activities, customers value the dimensions most in importance as follows: ability to solve problems, ambience and displays, willingness to assist customer by staff, range, hygiene, accuracy of signage, speed of response, individual attention and convenience when shopping. Supermarket shoppers have slightly different priorities when it comes to the dimensions of quality: courtesy, ambience and displays, accurate signage, 
individual attention, competitiveness, promise fulfilment, range, fast service, orderliness and accessibility.

$\mathrm{Hu}$, Liu, Su and Huang (2016) investigate differences in perceptions of the dimension of responsibility within the SERVQUAL analysis, if respondents are considered by gender. The survey was conducted at four retail outlets in Taiwan. The results of the study suggest that there is no statistically significant difference in the valuation of the five statements regarding the dimension of responsibility by men and women, although some previous studies confirm this.

Veloso, Ribeiro and Alves (2018) focus on measuring the dimensions of SERVQUAL analysis in the retail sector in Portugal. The authors state that 22 questions, viz. SERVQAL questionnaire statements can be reduced to three dimensions, and can be applied reliably to traditional forms of retail. In addition, the conclusion of this research is that the SERVQUAL model can be seen as a tool for improving the quality of service offered in traditional retail stores and, through increased customer satisfaction and loyalty, lead to better organization and greater profitability.

Karakitsiou and Mavrommati (2018) explore the six dimensions of SERVQUAL in retail outlets located in Greece. The authors used six dimensions in the test over the five standard ones because, based on a review of the relevant literature, they concluded that retail has certain specifics to consider. The results of the survey show that all six dimensions of SERVQUAL need to be worked in the retail outlets surveyed, as none of the performance of the dimensions met the expectations of the service users. On this basis, there is a clear space for improving the quality of services provided by the retail outlets covered by the survey.

Haming, Murdifin, Syaiful and Putra (2019) focus on examining customer perceptions of SERVQUAL analysis dimensions in Indonesia. As the need for research of this kind, the authors cite the reason for the potential improvement in the quality of service provided in retail outlets. The results of the research indicate that the priorities in building quality service to the customers examined are the dimensions of tangibility and empathy, followed by the dimensions of responsibility, reliability and safety, respectively.

The authors Sulistiyowati and Rofik (2018) are concerned with the implementation of SERVQUAL analysis in order to measure the quality of services provided in a retail store. The variables used in the research are the five classic dimensions of SERVQUAL, and based on the results of the research, the authors conclude that the responsibility dimension has a zero gap, which means that the expectations and performance of this dimension are equal, and that the security dimension has the largest negative gap (performance of the dimensions are less than expected).

\section{Research methodology}

\subsection{Aim of the research}

The aim of the study was to collect data on the views of customers who visited the selected retailer regarding claims related to the dimensions of the SERVQUAL model. Based on the degree of agreement with the performance and expectation of claims related to the dimensions of service quality, the goal is to determine whether there is a negative or positive gap between claims and expectations, and within which dimensions the SERVQUAL is the smallest, and within which is the largest.

\subsection{Subject of research}

The subject of the research is the views of customers of the selected hypermarket located in the Brcko District of Bosnia and Herzegovina. In order to investigate these points, on the basis of a random selection of a retail store entered in the register of retail outlets in the Chamber of Commerce of the Brcko District, the manager of the selected retail outlet was contacted. On the basis of discussions with the manager, a permit for exploration was obtained, i.e. reaching potential customers at the retail premises.

\subsection{Sample research}

A total of 38 (thirty-eight) customers were surveyed. Customers, i.e. the respondents were selected using the systematic sampling method, and the examiners approached every 10th customer who would enter the retail outlet.

\subsection{Research procedure}

For the purposes of research and to reach the empirical data in this paper, we used the survey method. The respondents were explained that the questionnaire was anonymous. The examiner also briefly explained to the respondents the subject and purpose of the research. 
Based on the literature dealing with the analysis and use of the SERVQUAL model, we have compiled a 22 (twenty-two)-question questionnaire according to the methodology provided by the authors of Parasuraman, Zeithaml, and Berry (1988), which is widely accepted and subsequently modified by many authors who write on the topic of service quality dimensions.

Customers were interviewed by the approach of the examiner at the time customers left the retail outlet. Following the consent of the customers to participate in the survey, the examiner orally asked the questions listed in the questionnaire and recorded the answers. The survey lasted one day between $8 \mathrm{am}$ and $5 \mathrm{pm}$.

\subsection{Statistical data processing}

Once the data were collected, data processing was started with the help of the SPSS statistical package. The questionnaire from which the data were collected consisted of 25 (twenty-five) questions. The first three questions concerned the demographics of respondents (gender, age and education). Gender and education are defined as nominal variables and education as a ratio variable. Other questions (22 questions) are related to the SERVQUAL model of service quality dimension research.

These questions are given in the form of statements, and are categorized into SERVQUAL model dimensions (tangible elements, reliability, responsibility, safety and empathy). On the one hand, respondents provided answers about the degree of agreement with statements regarding expectations, and on the other hand, respondents gave answers about the performance of a particular retail item, which is typical of the SERVQUAL model, and a 7 (seven) Likert scale was used to express the degree of agreement with respondents. The respondents expressed their degree of agreement with the statement in such a way that 1 (one) is the lowest and 7 (seven) the highest degree of agreement with the statement.

\section{Results of the research}

The results of the survey based on the data collected are below. Table 1 shows the demographic characteristics of the sample respondents related to nominal variables (gender and education. Based on the sample of 38 respondents, we can see that there were 17 men $(44.7 \%)$ and 21 women $(55.3 \%)$ In terms of education, 10 respondents $(26.3 \%)$ have completed a college, master's or doctoral degree, 28 respondents $(73.7 \%)$ have a university degree, and none of them has only a primary school education.

Table 1 Demographic characteristics of respondents (gender and education)

\begin{tabular}{l|r|r|r}
\hline $\begin{array}{l}\text { Demographic } \\
\text { characteristics } \\
\text { of respondents }\end{array}$ & Frequency & Percentage & $\begin{array}{l}\text { Cumulative } \\
\text { percentage }\end{array}$ \\
\hline Pol & 17 & 44,7 & 44,7 \\
\hline Male & 21 & 55,3 & 100,0 \\
\hline Female & 38 & 100,0 & 100,0 \\
\hline Total & 10 & 26,3 & 26,3 \\
\hline Education & 28 & 73,7 & 100,0 \\
\hline $\begin{array}{l}\text { Faculty, } \\
\text { Master's, Ph.D. }\end{array}$ & & & \\
\hline $\begin{array}{l}\text { High school } \\
\text { education }\end{array}$ & 0 & 0,0 & \\
\hline $\begin{array}{l}\text { Primary } \\
\text { education }\end{array}$ & 38 & 100,0 & 100,0 \\
\hline Total & & \multicolumn{2}{|c}{ Source: The author }
\end{tabular}

Table 2 presents age data of the respondents expressed in years. The average age of the respondents is 38.87 with a standard deviation of 15.80 . The minimum value of variable age is 18 , the maximum value is 73 years.

Table 2 Age of the sample respondents

\begin{tabular}{l|c}
\hline Age of respondents & Value \\
\hline Average value & 38,87 \\
\hline Standard deviation & 15,80 \\
\hline Minimum & 18 \\
\hline Maximum & 73 \\
\hline & Source: The author
\end{tabular}

Data on mean values and standard deviation of the degree of agreement with the statements from the SERVQUAL model questionnaire are shown in Table 3 . The 22 statements are categorized into five dimensions of service quality: reliability ("Promised service fulfilled", "Customer problems solved", "Service is good 'from the first' ", "Service delivered within the promised time", "Service is delivered without error"), responsibility ("Customers are informed about the delivery time", "Service is performed quickly", "Employees are ready to help the customer ", "Employees are ready to respond to requests "), security ("Employees instill confidence in customers", "Customers feel safe when paying", "Employees are polite", "Employees know how to respond to customers"), empathy ("Customers are given individual attention", "Employees take care of customers", "Customers come first to employees ", "Employees understand customer needs", "Working time is customized for customers"), tangible elements 
("Retail is modern", "Retail is visually appealing", "Employees are uniformed and tidy", "Equipment in the facility is adequate for services").

When it comes to performance, the highest median value is the statement "Employees are ready to respond to requests" with a mean of 5.24 and a standard deviation of 1.05 . The lowest mean value is shared by the claims "Retail is modern" (mean 4.24 with standard deviation 1.02) and the statement "Equipment in the facility is adequate for services" (mean 4.24 with standard deviation 1.42). Other dimensions of performance have the following mean values and standard deviations: "Promise service fulfilled" (mean 4.63 with standard deviation 0.94), "Customer problems solved" (mean 4.55 with standard deviation 0,83 ), "Service is good" from the first "' (mean 4.53 with standard deviation 0.83 ), "Service delivered within the promised time" (mean 4.58 with standard deviation 0.92), "Service is delivered without error " (mean 4.63 with standard deviation 0.85), "Customers are informed about delivery time" (mean 4.76 with standard deviation 1.17), "Service is performed quickly" (mean 4.95 with standard deviation 1.21), "Employees are ready to help the customer" (mean 5.03 with standard deviation 1.08), "Employees instill confidence in customers" (mean 4.45 with standard deviation 1.62), "Customers feel safe when paying" (mean 4.92 with standard deviation 1.57), "Employees are polite" (mean 4.61 with standard deviation 1.41), "Employees have the knowledge to respond to customers" (mean 4.58 with standard deviation 1.65), "Customers are given individual attention" (mean 4.87 with standard deviation 1.34), "Employees take care of customers" (mean value 4.47 with standard deviation 1.31), "Customers come first to employees" (mean 4.66 with standard deviation 1.32), "Employees understand customer needs" (mean 4.29 with standard deviation 1.51), "Working time is customized for customers" (mean 4.82 with standard deviation 1.49), "Retail is visually appealing" (mean 4.45 with standard deviation 1.13), and "Employees are uniformed and tidy" (mean 4.47 with standard deviation 1.08).

In terms of expectations, the statement "Working time is customized for customers" has the highest mean value (mean 6.74 with a standard deviation of 0.60 ), while the lowest mean value has the claim "Customers come first to employees" (mean 4.87 with standard deviation 1.17). Other dimension of expectations have the following mean values and standard deviations: "Promised service fulfilled" (mean 6.66 with standard deviation 0.63), "Customer problems solved" (mean 6.50 with standard deviation 0.69), "Service is good 'from the first' " (mean 6.61 with standard deviation 0.59), "Service delivered within the promised time" (mean 6.45 with standard deviation $0.69)$, "Service is delivered without error "(mean 6.11 with standard deviation 0.80 )," Customers are informed about the delivery time "(mean 6.50 with standard deviation 0.51), "Service is performed quickly" (mean 6.53 with standard deviation 0.60 ), "Employees are ready to help the customer" (mean 6.37 with standard deviation 0.59), "Employees instill confidence in customers" (mean 6.66 with standard deviation 0.58), "Customers feel safe when paying" (mean 6.63 with standard deviation 0,54), "Employees are polite" (mean 6.53 with standard deviation 0.65), "Employees know how to respond to customers "(mean 6.61 with standard deviation 0.55), "Customers are given individual attention" (mean 5.29 with standard deviation 0.93), "Employees take care of customers "(mean value 6.08 with standard deviation 1.22), "Employees understand customer needs" (mean 5.84 with standard deviation 0.79), "Retail is visually appealing" (mean 5.16 with standard deviation 0.79), and "Employees are uniformed and tidy" (mean 6.26 with standard deviant 0.83 ), "Employees are ready to respond to requests" (mean 6.47 with standard deviation 0.69), "Retail is modern" (mean 4.89 with standard deviation 0.80 ) and assertion "Facility equipment is adequate for services" (mean 6.66 with a standard deviation of 0.48).

Table 3 Degree of assertion (retailer performance and customer expectations)

\begin{tabular}{|c|c|c|c|c|c|}
\hline 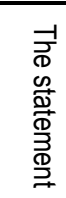 & $\mathrm{N}$ & 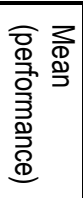 & 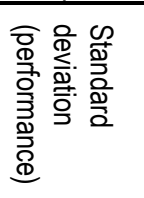 & 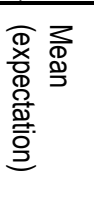 & 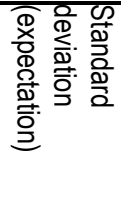 \\
\hline $\mathrm{S} 1$ & 38 & 4.63 & 0.94 & 6.66 & 0.63 \\
\hline S2 & 38 & 4.55 & 0.83 & 6.50 & 0.69 \\
\hline S3 & 38 & 4.53 & 0.83 & 6.61 & 0.59 \\
\hline S4 & 38 & 4.58 & 0.92 & 6.45 & 0.69 \\
\hline S5 & 38 & 4.63 & 0.85 & 6.11 & 0.80 \\
\hline S6 & 38 & 4.76 & 1.17 & 6.50 & 0.51 \\
\hline S7 & 38 & 4.95 & 1.21 & 6.53 & 0.60 \\
\hline S8 & 38 & 5.03 & 1.08 & 6.37 & 0.59 \\
\hline S9 & 38 & 5.24 & 1.05 & 6.47 & 0.69 \\
\hline $\mathrm{S} 10$ & 38 & 4.45 & 1.62 & 6.66 & 0.58 \\
\hline $\mathrm{S} 11$ & 38 & 4.92 & 1.57 & 6.63 & 0.54 \\
\hline $\mathrm{S} 12$ & 38 & 4.61 & 1.41 & 6.53 & 0.65 \\
\hline $\mathrm{S} 13$ & 38 & 4.58 & 1.65 & 6.61 & 0.55 \\
\hline $\mathrm{S} 14$ & 38 & 4.87 & 1.34 & 5.29 & 0.93 \\
\hline $\mathrm{S} 15$ & 38 & 4.47 & 1.31 & 6.08 & 1.22 \\
\hline
\end{tabular}




\begin{tabular}{l|l|l|l|l|l}
\hline S16 & 38 & 4.66 & 1.32 & 4.87 & 1.17 \\
\hline S17 & 38 & 4.29 & 1.51 & 5.84 & 0.79 \\
\hline S18 & 38 & 4.82 & 1.49 & 6.74 & 0.60 \\
\hline S19 & 38 & 4.24 & 1.02 & 4.89 & 0.80 \\
\hline S20 & 38 & 4.45 & 1.13 & 5.16 & 0.79 \\
\hline S21 & 38 & 4.47 & 1.08 & 6.26 & 0.83 \\
\hline S22 & 38 & 4.24 & 1.42 & 6.66 & 0.48 \\
\hline
\end{tabular}

\section{Discussion}

The research findings in the previous section of the paper point to several facts. If we generally consider all dimensions of the SERVQUAL model, the gap between performance and service expectations is negative across all dimensions. The performance of the services provided by retail outlets is below the expectations of the surveyed service users. The problem in determining the difference between the mean values of the degree of agreement with the performance statements and the expectations in this study is, first of all, the values of the Cronbach's alpha coefficient. Cronbach's alpha values by dimensions (performance) are: reliability (alpha $=0.89$ ), responsibility $($ alpha $=0.87)$, security $($ alpha $=$ 0.90), empathy (alpha $=0.88$ ) and tangible elements (alpha $=0.90)$. Cronbach's alpha coefficients by dimensions (expectations) are: reliability (alpha $=0.60)$, responsibility $($ alpha $=$ $0.88)$, security $($ alpha $=0.72)$, empathy $($ alpha $=$ 0.15 ), and tangible elements (alpha $=0.06$ ). Based on the results that can be compared, which results from the application of internal consistency indicators, i.e. Cronbach's alpha coefficient, we can conclude that the following statements are sorted by dimensions of service quality: reliability, accountability and safety. Claims within the empathy dimensions and tangible elements cannot be compared because of the extremely low values of the Cronbach's alpha coefficient, namely: 0.15 and 0.06 respectively. According to this, only data on the difference between performance and expectations for those dimensions that have an acceptable Cronbach's alpha coefficient are shown in Table 4.

Table 4 Difference between performance and expectations

\begin{tabular}{l|c|c}
\hline Statement & $\mathbf{N}$ & $\begin{array}{c}\text { Mean(performance) - } \\
\text { Mean(expectation) }\end{array}$ \\
\hline $\begin{array}{l}\text { The promise of service } \\
\text { is fulfilled }\end{array}$ & 38 & $-2,03$ \\
\hline $\begin{array}{l}\text { Customer problems } \\
\text { are being addressed }\end{array}$ & 38 & -1.95 \\
\hline $\begin{array}{l}\text { The service is good } \\
\text { "from the first" }\end{array}$ & 38 & -2.08 \\
\hline $\begin{array}{l}\text { The service was } \\
\text { delivered on time }\end{array}$ & 38 & -1.87 \\
\hline
\end{tabular}

\begin{tabular}{l|l|l}
\hline $\begin{array}{l}\text { The service is } \\
\text { delivered without error }\end{array}$ & 38 & -1.47 \\
\hline $\begin{array}{l}\text { Customers are notified } \\
\text { of the delivery time }\end{array}$ & 38 & -1.74 \\
\hline $\begin{array}{l}\text { The service is } \\
\text { executed quickly }\end{array}$ & 38 & -1.58 \\
\hline $\begin{array}{l}\text { Employees are ready } \\
\text { to help the customer }\end{array}$ & 38 & -1.34 \\
\hline $\begin{array}{l}\text { Employees are ready } \\
\text { to respond to requests }\end{array}$ & 38 & -1.24 \\
\hline $\begin{array}{l}\text { Employees instill } \\
\text { confidence in } \\
\text { customers }\end{array}$ & 38 & $-2,21$ \\
\hline $\begin{array}{l}\text { Customers feel safe } \\
\text { when paying }\end{array}$ & 38 & $-1,71$ \\
\hline $\begin{array}{l}\text { The employees are } \\
\text { kind }\end{array}$ & 38 & $-1,92$ \\
\hline $\begin{array}{l}\text { Employees have the } \\
\text { knowledge to respond } \\
\text { to customers }\end{array}$ & 38 & $-2,03$ \\
\hline
\end{tabular}

Source: The author

In this way, the biggest difference between performance and expectations is in the statement "Employees instill confidence in customers" (2.21). The smallest difference between performance and expectations is in the statement "Employees are ready to respond to requests" (1.24). Other differences in the claims are: "Promised service fulfilled" (-2.03), "Customer problems solved" (-1.95), "Service is good 'from the first' " (-2.08), "Service delivered within the promised time" (-1.87), "Service is delivered without error" (-1.47), "Customers are informed about delivery time" (-1.74), "Service is performed quickly" (-1.58), "Employees are ready to help the customer" (-1.34), "Customers feel safe when paying" (-1.71), "Employees are polite" (-1.92) and "Employees have the knowledge to respond to customers" (-2.03).

Managers of the retail outlet subject to the survey have space for progress in delivering quality, but relatively small deviations from performance, as it is a seven-step Likert scale, suggest that the situation in the retail outlet is not so bad. However, as a prerequisite for satisfaction, it is necessary to take measures to improve the quality of all dimensions of services and thus lead to greater loyalty of service users and greater profitability of the retail outlet.

\section{Conclusion}

SMEs are beginning to understand the importance of the customer in delivering value, whether it is tangible products or services. Of course, in addition to customers, one needs to monitor other elements of the microenvironment. In relation to tangible products, services have certain 
specificities that make it difficult, among other things, to differentiate them from competitors. However, services must be offered to the market in order to be unique. Due to the above, it is necessary to pay attention to the development and improvement of the dimensions of services. In order to adequately develop the dimensions of services, it is necessary to observe the dimensions of the services through the eyes of customers. This means that models of evaluation of service dimensions need to be developed.

The two generally accepted models are the GAP model and the SERVQUAL model. This paper focuses on the SERVQUAL model in retail. The SERVQUAL model is based on the GAP model, and its essence is to compare consumers' perceptions with their expectations. The premise of the model is five dimensions: tangible elements, reliability, responsibility, security and empathy. The results of the survey show that when looking at performance, the smallest mean value is shared by the claims "Retail is modern" and the statement "Equipment in the facility is adequate for services" and the largest "Employees are ready to respond to requests". Looking at expectations, the statement "Working time is customized for customer" has the highest average value, while the statement "Customers come first to employees" is the lowest.

The Cronbach's alpha coefficient was used to measure the internal consistency of the questionnaire, which showed that the two dimensions within the expectations did not meet the criteria to be taken for further analysis. This suggests that the dimensions need to be modified and adapted to the retail service sector.

There are several limitations to this paper. First, the sample size of 38 subjects is sufficient for statistical processing but not for generalizing conclusions. Secondly, the question of the relevance of using the SERVQUAL model for evaluating the dimensions of service quality is raised because, as in many studies that can be found in the relevant literature, the problem of internal consistency of dimensions as a rating factor arises in this research. This is particularly reflected in the fact that, specifically in this paper, two dimensions of quality are omitted from further analysis of differences between performance and expectations. Third, the research focuses only on retail as one service sector.

One recommendation for future research would be to do a similar survey with a larger sample of both retail outlets and respondents, i.e. customers. In addition, research should be conducted with a modified SERVQUAL model, which would address the issue of internal consistency of the model. It would also be interesting to conduct a survey covering multiple service sectors and to compare the results obtained.sm

\section{References}

Bolton, C., Machová, V., Kovacova, M., \& Valaskova, K. (2018). The power of human-machine collaboration: Artificial intelligence, business automation, and the smart economy. Economics, Management, and Financial Markets, 13(4), 51-56. https://doi.org/10.22381/EMFM13420184

Clottey, T. A., Collier, D. A., \& Stodnick, M. (2008). Drivers of customer loyalty in retail store environment. Journal of Service Science, 1(1), 35-48. https://doi.org/10.19030/jss.v1i1.4300

Evanschitzky, H., lyer, G. R., \& Caemmerer, B. (2008). Dimensions of satisfaction in retail settings: A research note. Journal of Relationship Marketing, 7(3), 275-285. https://doi.org/10.1080/15332660802409621

Grubor, A., Đokić, N., \& Milićević, N. (2017). Sale potentials of organic food in the autonomous province of Vojvodina in on-line business conditions. Strategic Management, 22(4), 19-23. https://doi.org/10.5937/StraMan1804026G

Haming, M., Murdifin, I., Syaiful, A. Z., \& Putra, A. H. P. K. (2019). The Application of SERVQUAL Distribution In Measuring Customer Satisfaction of Retails Company. Journal of Distribution Science, 17, 25-34. https://doi.org/10.15722/jds.17.2.201902.25

Hyers, D., \& Kovacova, M. (2018). The economics of the online gig economy: Algorithmic hiring practices, digital labor-market intermediation, and rights for platform workers. Psychosociological Issues in Human Resource Management, 6(1), 160-165. https://doi.org/10.22381/PIHRM6120187

Hu, Y. J., Liu, F. M., Su, L. C., \& Huang, J. H. (2016). Examining the measurement invariance across gender for the part of responsiveness in SERVQUAL scale in retail business of Taiwan. International Journal of Organizational Innovation (Online), 9(1), pp. 284-290.

Karakitsiou, A., \& Mavrommati, A. (2018). Service quality assessment in retail industry: some evidence from supermarkets in Greece. International Journal of Decision Support Systems, 3(1-2), 128-142. https://doi.org/10.1504/IJDSS.2018.094258

Khare, A. (2013). Retail service quality in small retail sector: the Indian experience. Facilities, 31(5/6), pp. 208-222. https://doi.org/10.1108/02632771311307089

Kimani, S. W., Kagira, E. K., Kendi, L., \& Wawire, C. M. (2012). Shoppers perception of retail service quality: supermarkets versus small convenience shops (Dukas) in Kenya. Journal of management and strategy, 3(1), pp.55-66

Končar, J., \& Leković, S. (2016). The role of retail strategy in the development and efficiency of business on the global electronic market. Strategic Management, 21(4), 22-28.

Končar, J., Grubor, A., \& Marić, R. (2019). Improving the placement of food products of organic origin on the AP Vojvodina market. Strategic Management, 24(3), 24-32. https://doi.org/10.5937/StraMan1903024K 
Lee-Ross, D. (2008). An exploratory study of the contextual stability of SERVQUAL amongst three retail clusters in far North Queensland. Journal of Place Management and Development, 1(1), 46-61. https://doi.org/10.1108/17538330810865336

Martinelli, E., \& Balboni, B. (2012). Retail service quality as a key activator of grocery store loyalty. The Service Industries Journal, 32(14), 2233-2247. https://doi.org/10.1080/02642069.2011.582499

Mitea, D. R. E. (2018). The expansion of digitally mediated labor: platform-based economy, technology-driven shifts in employment, and the novel modes of service work. Journal of Self-Governance and Management Economics, 6(4), 7-13. https://doi.org/10.22381/JSME6420181

Nadiri, H., \& Tümer, M. (2009). Retail services quality and behavioural intentions: an empirical application of the retail service quality scale in Northern Cyprus. $E+M$. Ekonomie a Management = Economics and Management pp. 127-139

Naik, C. K., Gantasala, S. B., \& Prabhakar, G. V. (2010). Service quality (SERVQUAL) and its effect on customer satisfaction in retailing. European journal of social sciences, 16(2), pp. 231-243.

Nica, E. (2018). Will robots take the jobs of human workers? Disruptive technologies that may bring about jobless growth and enduring mass unemployment. Psychosociological Issues in Human Resource Management, 6(2), 56-61. https://doi.org/10.22381/PIHRM6220184

Nuševa, D., \& Marić, R. (2017). Quick response logistics in retailing as an information technology based concept. Strategic Management, 22(4), pp. 32-38.

Parasuraman, A., Zeithaml, V. A., \& Berry, L. L. (1988). Servqual: A multiple-item scale for measuring consumer perc. Journal of retailing, 64(1), pp. 12-40.

Prdić, N., Kuzman, B., \& Damjanović, J. (2019). Marketing research in the function of business efficiency. Ekonomika poljoprivrede, 66(4), 1039-1054. https://doi.org/10.5937/ekoPolj1904039P

\section{$\triangle$ Correspondence}

\section{Dejan Tešić}

University of East Sarajevo, Faculty of Economics Brcko Studentska 11, 76100, Brcko, Bosnia and Herzegovina E-mail: dejan.tesic.efb@gmail.com
Seth, N., Deshmukh, S. G., \& Vrat, P. (2005). Service quality models: a review. International journal of quality \& reliability management, 22(9), 913-949. https://doi.org/10.1108/02656710510625211

Sulistiyowati, W., \& Rofik, A. (2018). Implementation of SERVQUAL Method and Root Cause Analysis to Measure the Service Quality of Retail Company in PT." X". In 1st International Conference on Intellectuals' Global Responsibility (ICIGR 2017), pp. 301-306. https://doi.org/10.2991/icigr-17.2018.73

Sum, C. Y., \& Hui, C. L. (2009). Salespersons' service quality and customer loyalty in fashion chain stores: A study in Hong Kong retail stores. Journal of Fashion Marketing and Management, 13(1), 98-108. https://doi.org/10.1108/13612020910939905

Suuroja, M. (2003). Service quality-Main conceptualizations and critique. University of Tartu Economics and Business Working Paper. https://doi.org/10.2139/ssrn.486947

To, W. M., Tam, J. F., \& Cheung, M. F. (2013). Explore how Chinese consumers evaluate retail service quality and satisfaction. Service Business, 7(1), 121-142. https://doi.org/10.1007/s11628-012-0149-7

Veloso, C. M., Ribeiro, H., \& Alves, S. R. (2018). Towards a Service Quality Measure of the Portuguese Traditional Retail Industry. Economic and Social Development: Book of Proceedings, pp. 472-482.

Veljković, S. (2009). Marketing us/uga. Centar za izdavačku delatnost Ekonomskog fakulteta u Beogradu. ČUGURA print. Beograd.

Vochozka, M., Kliestik, T., Kliestikova, J., \& Sion, G. (2018). Participating in a highly automated society: how artificial intelligence disrupts the job market. Economics, Management, and Financial Markets, 13(4), 57-62. https://doi.org/10.22381/EMFM13420185 